\title{
The carbonic anhydrase of the Chinese crab Eriocheir sinensis: effects of adaption from tap to salt water
}

\author{
A. Olsowski ${ }^{1}$, M. Putzenlechner ${ }^{1}$, K. Böttcher ${ }^{2,3}$ \& K. Graszynski ${ }^{1}$ \\ ${ }^{1}$ Institut für Tierphysiologie, FU Berlin; Grunewaldstr. 34, D-12165 Berlin, Germany \\ ${ }^{2}$ Biologische Anstalt Helgoland (Zentrale); Notkestr. 31, D-22607 Hamburg, Germany \\ ${ }^{3}$ Medizinische Hochschule Hannover, Abt. Vegetative Physiologie; \\ Konstanty-Gutschow-Str. 8, D-30625 Hannover, Germany
}

\begin{abstract}
In the present investigation we studied the carbonic anhydrase (CA) in various tissues of Chinese crab Eriocheir sinensis which were acclimated to different salinities $(0,10,20,30 \%$ o). We found only negligible CA activity in haemolymph, heart, hypodermis, antennal gland, leg muscle and digestive gland, irrespective of the acclimation medium. However, high amounts of CA activity were found in the gills. In the case of the posterior gills, a strong dependence on the acclimatization of the animals was demonstrated; the highest activities were found in those adapted to tap water. To investigate the cellular distribution of the $\mathrm{CA}$ in the posterior gills, the additional enzyme activities were measured in all fractions of a differential centrifugation of the gill homogenate: $\mathrm{Na}^{+} / \mathrm{K}^{+}$ATP'ase (a marker for the plasmamembrane); lactate dehydrogenase ( $\mathrm{LDH}$; as marker for the cytosol); and succinate dehydrogenase ( $\mathrm{SDH}_{\text {; }}$ as marker for mitochondria). Independent of the acclimation salinity (0 or $36 \%$ salinity), we found about $70 \%$ of CA associated with the highest level of the $\mathrm{Na}^{+} / \mathrm{K}^{+}$-ATP'ase in the second $100000 \mathrm{~g}$ pellet (membrane fraction), while only $15 \%$ were found in the cytosolic fractions (associated with highest levels of LDH). We conclude that the carbonic anhydrase of posterior gills of the Chinese crab is mainly membrane-bound. Furthermore, the activity of $\mathrm{CA}$ shows a strong dependence on the salinity of the water in which the crabs were kept.
\end{abstract}

\section{INTRODUCTION}

In biological systems, the reaction $\mathrm{CO}_{2}+\mathrm{H}_{2} \mathrm{O} \rightleftharpoons \mathrm{HCO}_{3}{ }^{-}+\mathrm{H}^{+}$is catalyzed by the enzyme called carbonic anhydrase (CA). Since its discovery in mammalian red blood cells by Meldrum \& Roughton (1932), the CA was assumed to mainly facilitate the exchange of $\mathrm{CO}_{2}$ across respiratory epithelia (Cameron, 1979a). Besides this function, there is accumulating evidence supporting other physiological functions of CA, e.g. mineralization of calcified structures, acid base balance and, last but not least, ion transport (Henry, 1988b). With regard to crabs, it has been reported that CA activity, which is mainly localized in the posterior gills, is induced during acclimation of the animals to diluted media (Henry \& Cameron, 1982; Böttcher et al., 1990a) suggesting its possible role in ion regulation. Recently, the results of electrophysiological studies of posterior gills of tap water-adapted Chinese crabs suggested a participation of branchial $\mathrm{CA}$ in ion transport. The negative short-circuit current and the outside positive transepithelial potential difference, both reflecting active adsorption of $\mathrm{Cl}^{-}$ions, were shown to be sensitive to acetazolamide (Onken \& Graszynski, 1989; Onken et al., 1991). 
In the present investigation we studied the relation between environmental salinity and the activity of $\mathrm{CA}$ in various tissues of Chinese crabs. Furthermore, we focussed on the cellular localization of $\mathrm{CA}$ within the posterior gills of this crab species.

\section{MATERIALS AND METHODS}

Chinese crabs were obtained from commercial fishermen who caught the crabs in the Eider and Elbe rivers, both of which open out into the North Sea (Schleswig-Holstein, Germany). In the laboratories, the animals were kept at $10-12^{\circ} \mathrm{C}$ in running tap water $\left(\mathrm{Na}^{+} 2.0 \mathrm{mmol} / \mathrm{l} ; \mathrm{K}^{+} 0.08 \mathrm{mmol} / \mathrm{l} ; \mathrm{Ca}^{++} 3.0 \mathrm{mmol} / \mathrm{l} ; \mathrm{Cl}^{-} 1.7 \mathrm{mmol} / \mathrm{l}\right)$. In order to study the effects of salt water acclimation on CA activity, the animals were kept in artificial salt water (36\% "Tropic Marin Neu"-Tropicarium Buchschlag) for a minimum of two weeks. For comparison of CA activity in different organs, tissue samples were homogenized with a tight fitting glass Teflon potter (Braun) in ice-cold homogenization buffer (HB), containing $250 \mathrm{mmol} / \mathrm{l}$ sucrose, $20 \mathrm{mmol} / \mathrm{l}$ Hepes and $0.4 \mathrm{mmol} / 1 \mathrm{Na}_{2}$ EDTA adjusted to $\mathrm{pH} 7.25$ with Tris. All steps of preparation were carried out below $4{ }^{\circ} \mathrm{C}$ on ice, and aliquots of fractions were stored at $-20^{\circ} \mathrm{C}$ until use.

$\mathrm{CA}$ activity was determined by following the rate of appearance of protons using a modified technique described by Henry \& Kormanik (1985). Since the uncatalyzed hydration of $\mathrm{CO}_{2}$ is most easily measured at $0^{\circ} \mathrm{C}$ and with the presence of a suitable buffer, any acceleration of the uncatalyzed rate following addition of a sample may be attributed to the presence of CA in the sample (Maren, 1967). The assay buffer was a $25 \mathrm{mM} \mathrm{Na}$-diethylbarbitol buffer, which was adjusted to $\mathrm{pH} 8.4$ using $25 \mathrm{mM}$ citric acid solution and aerated with $\mathrm{N}_{2}$ gas for $60 \mathrm{~min}$ before use. One $\mathrm{ml}$ of ice-cold buffer was mixed with $0.2 \mathrm{ml}$ of the sample in a reaction chamber kept on ice. Under rapid stirring, $1 \mathrm{ml}$ of ice-cold distilled water, saturated with $\mathrm{CO}_{2}$, was added. The resulting change of $\mathrm{pH}$ was measured with $\mathrm{pH}$ meter (Knick Digital $\mathrm{pH}$ Meter, Typ 643) attached to a recorder (Linseis, Typ L 6522). Activity of CA is expressed according to Maren (1967) comparing the uncatalyzed $\left(t_{0}\right)$ and the catalyzed reaction time $\left(t_{e}\right)$ measured in seconds: $A=\left(t_{o} / t_{e}\right)-1$.

One unit (U) of CA activity (A) is defined as the concentration of enzyme in the final assay volume required to halve the uncatalyzed reaction time.

In all fractions several marker enzymes were measured. The three posterior gills of the Chinese crab (arthrobranchia VI, pleurobranchiae I, II) were removed and washed with ice-cold $\mathrm{HB}$. After removing the main vessel, gills were homogenized at $1400 \mathrm{rpm}$ with 30 strokes in a $10 \%(\mathrm{w} / \mathrm{v})$ homogenate.

In order to localize CA activity inside the posterior gills, the homogenate was poured through gauze (pore diameter $90 \mu \mathrm{m}$ ) and the obtained fraction ("homogenate") was centrifuged for $10 \mathrm{~min}$ at $500 \mathrm{~g}$ (Sorvall RC $5 \mathrm{~B}$, rotor SS34). The pellet $(500 \mathrm{~g})$ was discarded. The supernatant was centrifuged at $5000 \mathrm{~g}$ for $15 \mathrm{~min}$. The obtained supernatant was centrifuged for $60 \mathrm{~min}$ at $100000 \mathrm{~g}$ (Beckman L5-65 ultracentrifuge, rotor TI-60) to sediment a crude membrane pellet. This pellet was suspended in $\mathrm{HB}$ and centrifuged again in the ultracentrifuge for $60 \mathrm{~min}$ at $100000 \mathrm{~g}$. The resulting pellet (second $100000 \mathrm{~g}$ pellet) was dissolved in 2-4 ml HB. Activity of CA was completely inhibited in all fractions with $10^{-6} \mathrm{~mol} / \mathrm{l}$ acetazolamide. $\mathrm{Na}^{+} / \mathrm{K}^{+}$-ATP'ase activity, localized in the basolateral membrane of epithelial gill cells (Towle \& Kays, 1986), was determined measuring the 
liberated inorganic phosphate according to Kosiol et al. (1988). Succinate dehydrogenase (SDH) activity, a marker for mitochondrial contamination, was measured according to the methods used by Clarke \& Porteous (1964) and Green \& Narahara (1980). Lactate dehydrogenase (LDH) is a well known marker enzyme for cytosolic fractions and was measured using the method of Scalera et al. (1980). Protein content was determined according to Bradford (1976) which was modified corresponding to Sedmark \& Grossberg (1977) using BSA as a standard.

\section{RESULTS}

\section{Distribution of CA activity in different organs of Eriocheir sinensis}

In Figure 1, the specific activity of $\mathrm{CA}$ is shown in different organs of Eriocheir sinensis. No activity could be detected in the hemolymph which is consistent with other investigations (Brinkman, 1933; Ferguson et al., 1937; Sobotka \& Kann, 1941; Henry \& Cameron, 1982; Böttcher et al., 1990a). Only a little CA activity was measured in heart, hypodermis and antennal gland; values did not exceed $3 \mathrm{U} / \mathrm{mg}$ protein. Highest levels of CA activity were found in the respiratory epithelia and in cells involved in ion transport, i.e. the gills. In the crabs adapted to tap water, CA activity was high in the posterior gills (ca $40 \mathrm{U}$ ) and was found to exceed that of the anterior gills by 3 -fold. When adapting crabs to salt water $(10,20$ and $30 \%$ salinities) the specific activity of CA decreased in posterior gills; whereas the activity in anterior gills remained almost unchanged (see Fig.1).

\section{Distribution of marker enzymes within the posterior gills}

Tables 1 and 2 show the specific and fractional activities of CA and the marker enzymes indicating that differential ultracentrifugation of posterior gill homogenates separated cytoplasm from the microsomal fraction. The specific activity of $\mathrm{Na}^{+} / \mathrm{K}^{+}$. ATP'ase was predominantly found in the second $100000 \mathrm{~g}$ pellet and was concentrated (by factor 3 ) when compared with activity of the homogenate. This pellet also contained the main portion of $\mathrm{Na}^{+} / \mathrm{K}^{+}$-ATP'ase. Recovery of enzyme activity was calculated by multiplying the sum of the enzyme activity in the particular fractions of the differential centrifugation with $100 \%$ and divided by the enzyme activity of the homogenate. There was a $75 \%$ recovery of $\mathrm{Na}^{+} / \mathrm{K}^{+}$-ATP'ase, of which $50 \%$ accumulated in the second $100000 \mathrm{~g}$ pellet. Besides $\mathrm{Na}^{+} / \mathrm{K}^{+}$-ATP'ase, this fraction contained some SDH activity ( $15 \%$ of the recovered enzyme activity) which was due to mitochondrial contamination.

The cytosolic marker enzyme, LDH, was detected almost exclusively in the $100000 \mathrm{~g}$ supernatant $\left(95 \%\right.$ of the recovered enzyme activity). Since there were no $\mathrm{Na}^{+} / \mathrm{K}^{+}$ATP'ase or SDH activities in this fraction, we concluded that the $100000 \mathrm{~g}$ supernatant predominantly contained the cytosolic enzymes of gill epithelial cells.

\section{Distribution of CA activity within the gill cells}

From Figure 2 it is obvious that the main portion of total CA activity (70\%) accumulated in the second $100000 \mathrm{~g}$ pellet (microsomal fraction). Only $15 \%$ of the CA activity was found in the $100000 \mathrm{~g}$ supernatant (= cytosolic fraction) (Fig. 2). Taking into 


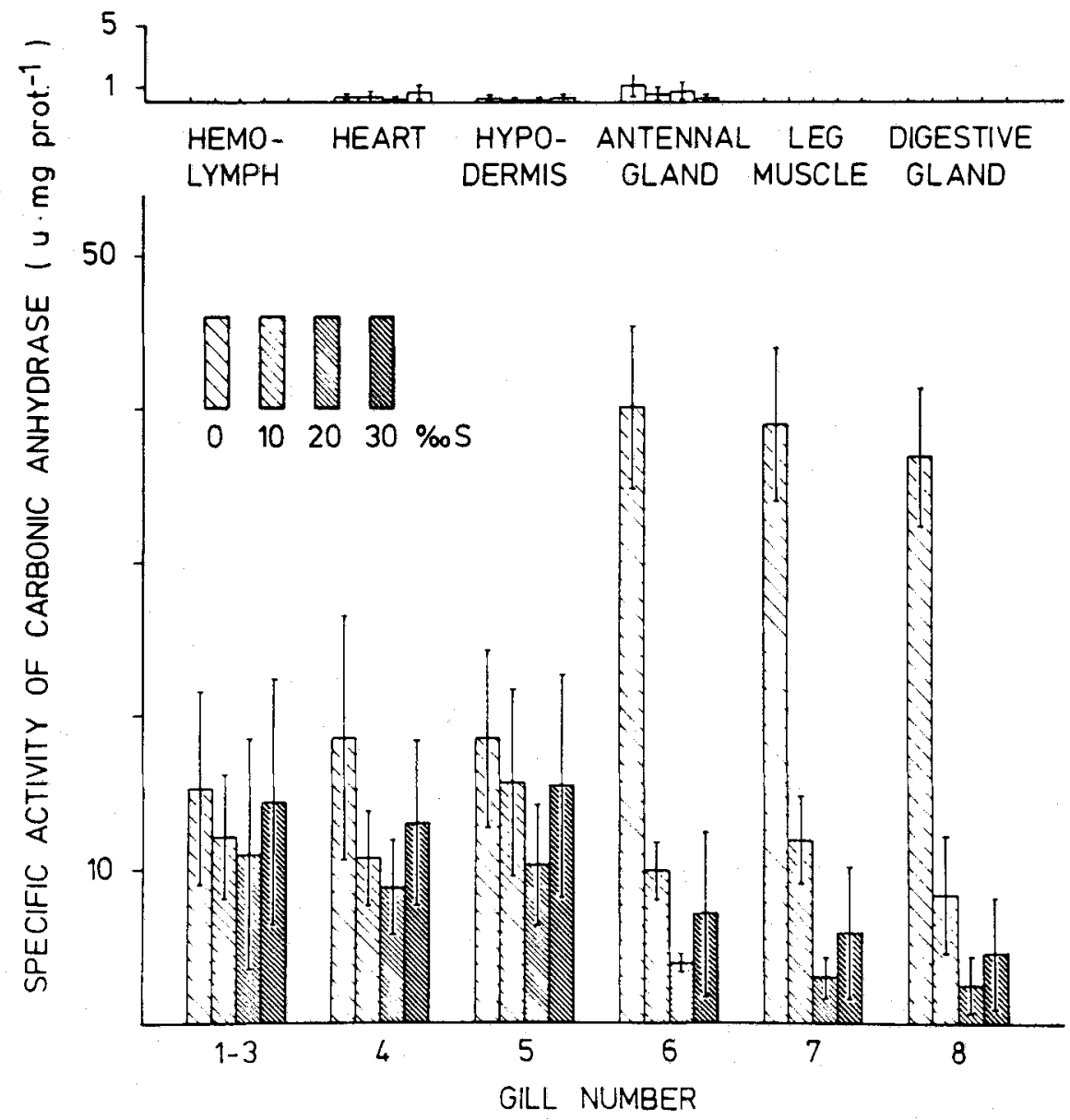

Fig. 1. Distribution of specific CA activity in different organs of the crab Eriocheir sinensis after adaptation to different salinities; data represent means \pm S.D. $(n=6)$

account that the $500 \mathrm{~g}$ pellet and the $5000 \mathrm{~g}$ pellet contained about $15 \%$ of the recovered CA activity, it is assumed that about $85 \%$ of CA activity was associated to membrane. Specific activities enriched by a factor of 7.2 (tap water) and 5.5 (salt water) in the microsomal fraction. Nearly no enzyme was lost as indicated by a recovery of $98 \%$ CAactivity. A concentration of $10^{-6} \mathrm{~mol} / \mathrm{l}$ acetazolamide completely inhibited CA in all fractions, indicating high sensitivity of this enzyme to sulfonamide inhibitors.

\section{Effects of acclimation from tap to salt water}

The effects of environmental salinity on the carbonic anhydrase activities in the gills are shown in Figure 3. When the animals were adapted from tap to salt water, the total CA activity in the homogenate dropped from $48 \mathrm{U} / \mathrm{mg}$ protein to $10 \mathrm{U} / \mathrm{mg}$ protein. A 


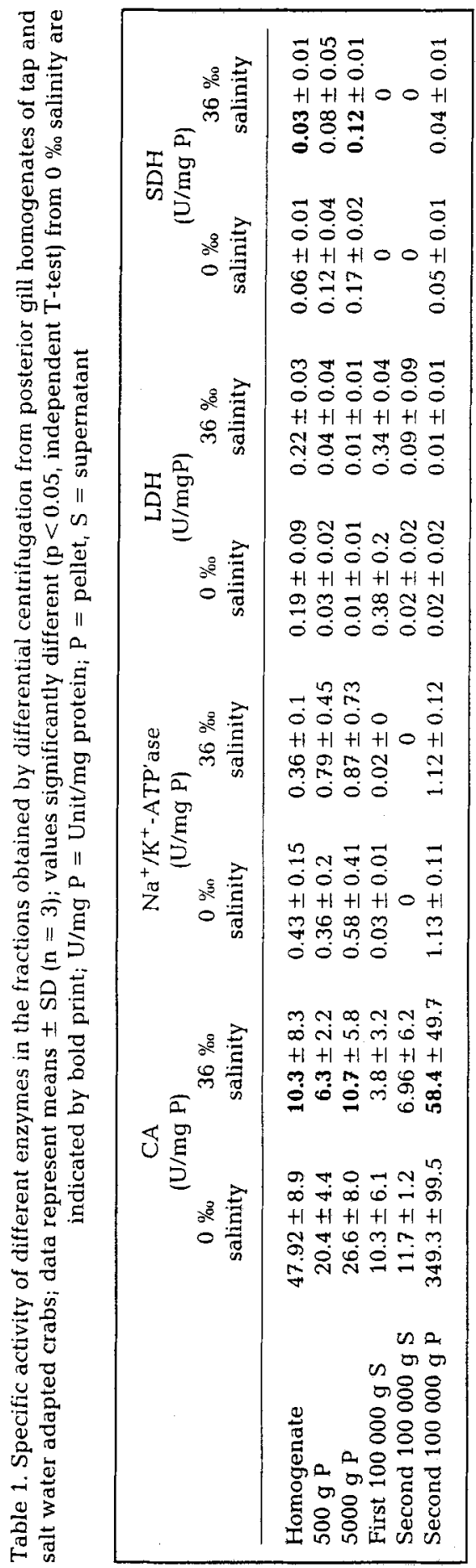

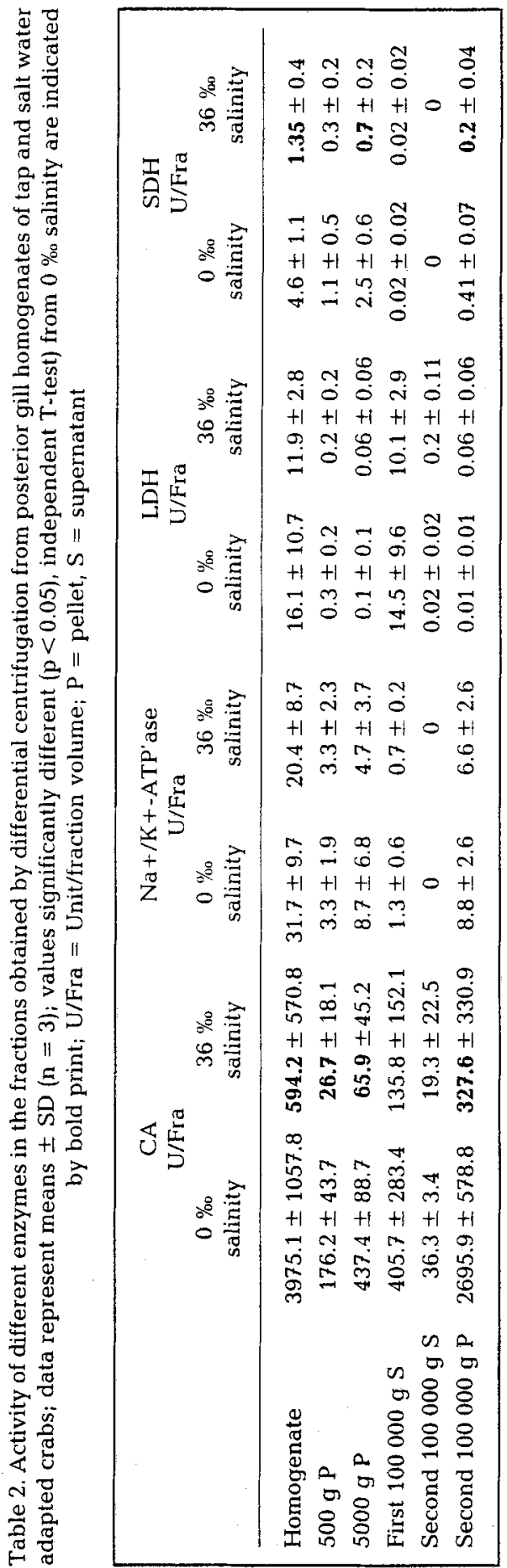




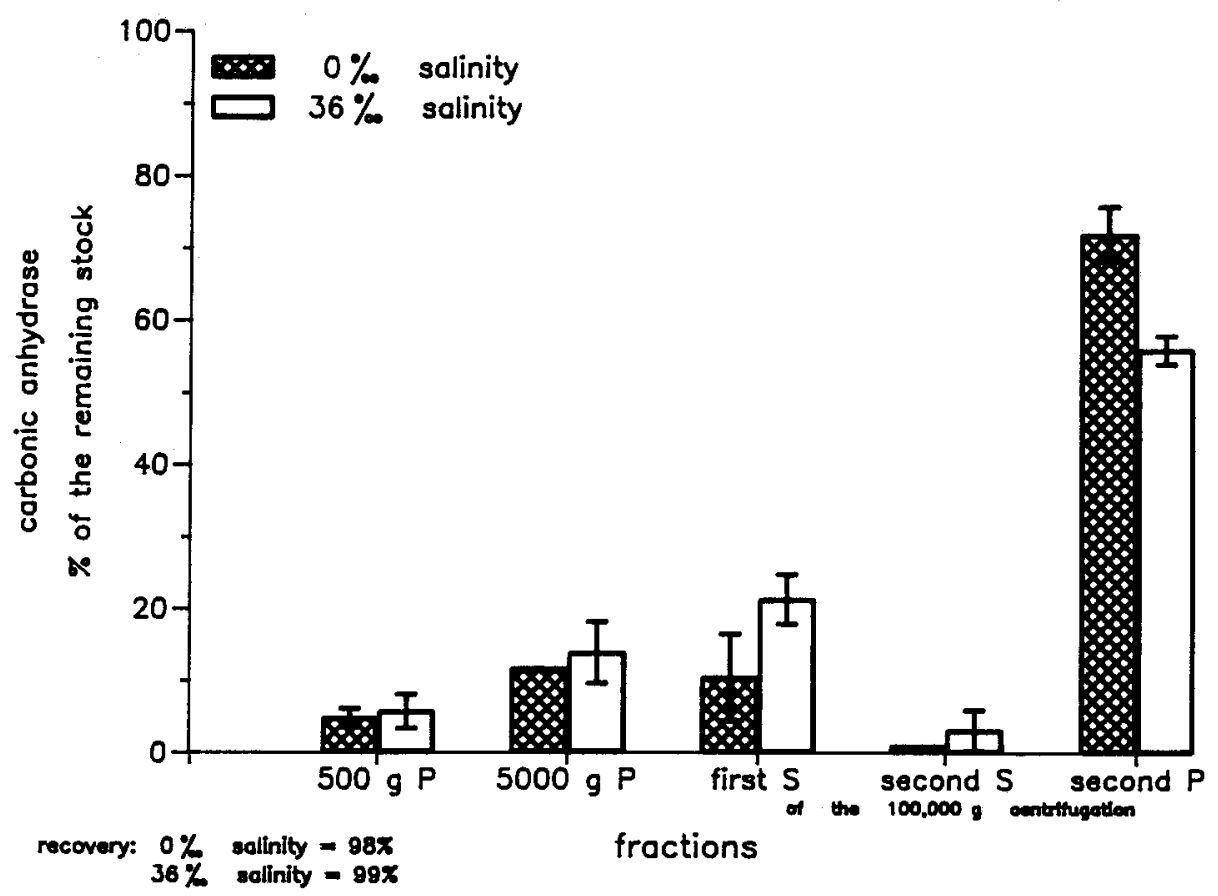

Fig. 2. Distribution of the CA activity with regard to the recovery. The recovery was set at $100 \%$ (the remaining stock) and the measured activity is in relation to this; data represent means $\pm S . D .(n=3)$, $\mathrm{P}=$ pellet, $\mathrm{S}=$ supernatant

decrease was found as well in the fractional CA activity: from $4000 \mathrm{U} / \mathrm{fraction}$ to $600 \mathrm{U} /$ fraction (Table 2).

The microsomal fraction exhibited much greater differences in CA activity when the assimilations to tap and salt water were compared. In the tap water assimilation, CA activity of this fraction revealed values decreasing from $350 \mathrm{U} / \mathrm{mg}$ protein $(2700 \mathrm{U} /$ fraction) to $60 \mathrm{U} / \mathrm{mg}$ protein ( $330 \mathrm{U} /$ fraction). In the cytosolic fraction, effects of adaptation were also remarkable; though the CA activity was altogether much lower here than in the homogenate and microsomal fraction. During adaptation the values of cytosolic $\mathrm{CA}$ activity decreased from $10.5 \mathrm{U} / \mathrm{mg}$ protein (438 U/fraction) to $4 \mathrm{U} / \mathrm{mg}$ protein (66 U/ fraction).

When comparing $\mathrm{Na}^{+} / \mathrm{K}^{+}$-ATP'ase, $\mathrm{LDH}$ and $\mathrm{SDH}$, only the mitochondrial enzyme $\mathrm{SDH}$ showed a significant decrease of $4.5 \mathrm{U} / \mathrm{fraction}$ (tap water adapted crabs) to $1.2 \mathrm{U} /$ fraction (salt water adapted crabs) in the homogenate (Table 2). The protein content of the homogenate declined during adaptation from $82.9 \mathrm{mg} /$ fraction to $53.9 \mathrm{mg} /$ fraction (data not shown).

\section{DISCUSSION}

Investigations on the physiological role of $\mathrm{CA}$ revealed that $\mathrm{CA}$ is not only involved in respiratory function, but also takes part in ion transport. The CA blocker acetazolamide inhibited $\mathrm{Na}^{+}$and $\mathrm{Cl}^{-}$influxes in some fresh water (Ehrenfeld, 1974) and euryhaline 


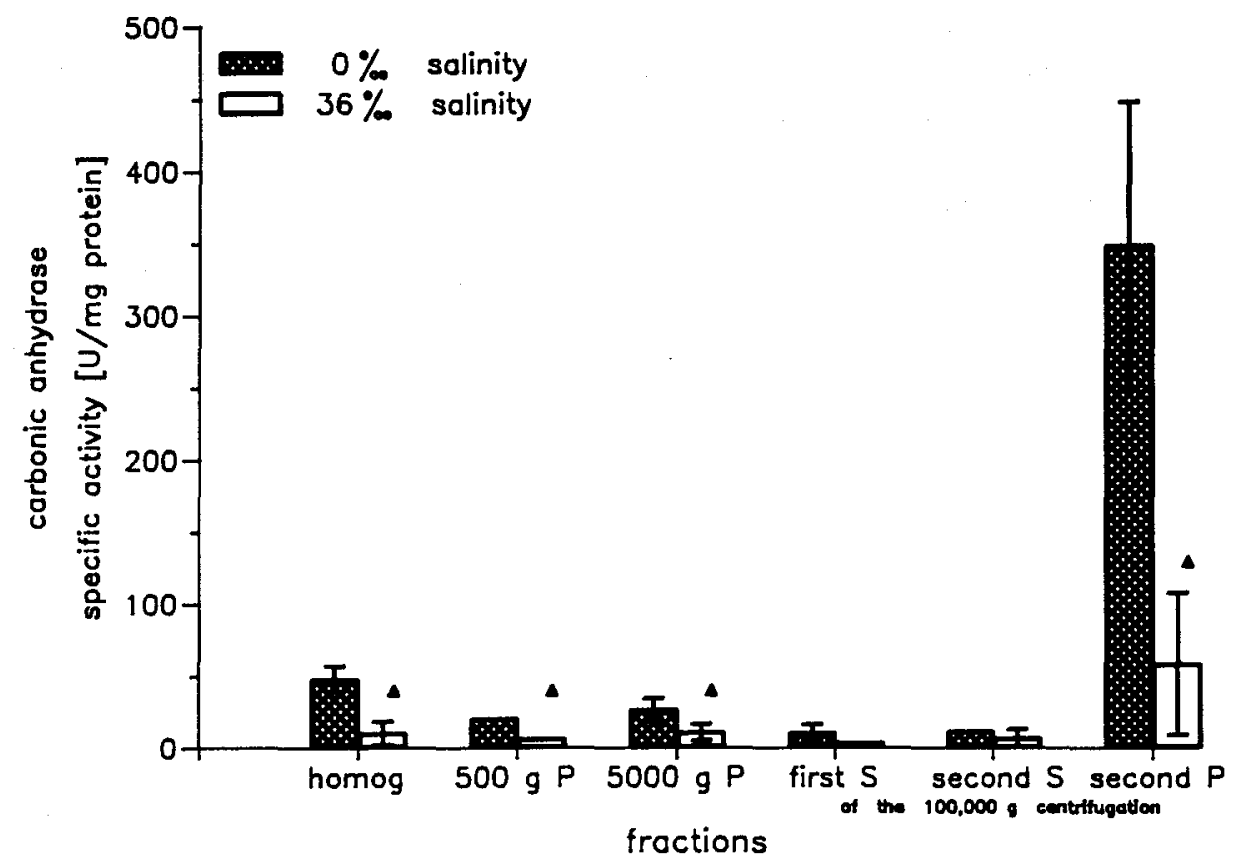

Fig. 3. Specific activity of the carbonic anhydrase in the fractions obtained from differential centrifugation; data represent means \pm S.D. $(n=3)$; values significantly different $(p<0.05$, independent $T$-test) from $0 \%$ salinity are indicated by triangle $(\Lambda) ; P=$ pellet, $S=$ supernatant

crustaceans (Cameron, 1979b). Furthermore, electrophysiological studies on posterior gills of Chinese crabs adapted to tap water revealed a $\mathrm{Cl}^{-}$-dependent short circuit current which was highly sensitive to acetazolamide (Onken et al., 1991). The present finding that the main portion of CA activity is localized in the posterior gills supports former investigations, that the posterior gills of Eriocheir sinensis represent the region where the majority of ion transport takes place (Pequeux \& Gilles, 1988).

From our results revealing the distribution of the membrane marker enzyme $\mathrm{Na}^{+} / \mathrm{K}^{+}$ATP'ase, as well as the location of the majority of CA activity in the cells, it may be concluded that the $\mathrm{CA}$ in the posterior gills of $E$. sinensis is mainly membrane-bound. Preponderant occurrence of CA activity in the plasma membranes of posterior gills of shore crabs Carcinus maenas was found by Böttcher et al. $(1990 \mathrm{a}, \mathrm{b})$ using differential and density gradient centrifugations.

Investigations of branchial CA in the blue crab Callinectes sapidus showed that the main portion of CA was concentrated $(93.5 \%$ ) in the cytosol (Henry, 1988a). Only a minor portion was located the plasma membrane. In these experiments, the amount of membrane-bound CA activity increased about 50 and $100 \%$, when acclimated to a salinity of $12 \%$. The major changes in branchial CA activity were attributed to the 20 -fold increase of cytoplasmic CA.

According to Henry (1988a), membrane-bound CA deals mainly with $\mathrm{CO}_{2}$ excretion, whereas cytosolic $\mathrm{CA}$ is involved in ion transport. However, the minor soluble amount of 
membraneous environment by rough treatment of homogenates and pellets. On the other hand, this cytosolic CA could represent a first stage, intended for integration into the membrane. Nevertheless, a participation of cytosolic CA in ion transport cannot be ruled out, since acetazolamide is able to permeate membranes easily. This problem should be solved in future experiments by the use of impermeable specific inhibitors (Henry, 1987; Burnett \& McMahon, 1985).

According to the effects of adaptation, we found the membrane-bound CA activity about 6 times higher in tap-water-adapted crabs compared with salt-water-adapted crabs. These data agree well with the results of Böttcher et al. (1990a) who found a significant branchial increase of $\mathrm{CA}$ after acclimation of $C$. maenas to low salinities. Due to the necessity of inward $\mathrm{Cl}^{-}$transport in tap water, the increase of $\mathrm{CA}$ activity seems to be a response to the external low $\mathrm{Cl}^{-}$concentration. But here some contradictions arise: In $E$. sinensis, the results derived from electrophysiological and biochemical investigations indicated that electrogenic $\mathrm{Cl}^{-}$transport depends on the cooperation of a proton pump and the CA (Onken et al., 1995). In contrast, experiments on C. maenas concerning potential difference, fluxes of $\mathrm{Na}^{+}$and $\mathrm{Cl}^{-}$(Böttcher et al., 1991) and short circuit current experiments (Onken \& Siebers, 1992) do not reveal any participation of CA activity in $\mathrm{Na}^{+} / \mathrm{Cl}^{-}$transport.

Despite the differences between these closely-related crabs, the effects of different external salinities on CA activity are quite impressive and, thus, CA activity seems to be related to ion transport at least in the case of $E$. sinensis.

Further research concerning exact localization, regulation of $\mathrm{CA}$ activity and related transport systems should help to answer the question concerning the function of CA in the posterior gills of the Chinese crab E. sinensis.

\section{LITERATURE CITED}

Böttcher, K., Siebers, D. \& Becker, W., 1990a. Carbonic anhydrase in branchial tissues of osmoregulating shore crabs, Carcinus maenas (L.). - J. exp. Zool. 255, 251-261.

Böttcher, K., Siebers, D. \& Becker, W., 1990b. Localization of carbonic anhydrase in the gills of Carcinus maenas. - Comp. Biochem. Physiol. 96 B, 243-246.

Böttcher, K., Siebers, D., Becker, W. \& Petrausch, G., 1991. Physiological role of branchial carbonic anhydrase in the shore crab Carcinus maenas. - Mar. Biol. 110, 337-342.

Bradford, M. M., 1976. A rapid and sensitive method for the quantitation of microgram quantities of protein utilizing the principle of protein dye binding. - Analyt. Biochem. 72, 248-254.

Brinkman R., 1933. The occurrence of carbonic anhydrase in lower marine animals. - J. Physiol., Lond. $80,171-173$.

Burnett, L. E. \& McMahon, B. R., 1985. Facilitation of $\mathrm{CO}_{2}$ excretion by carbonic anhydrase located on the surface of the basal membrane of crab gill epithelium. - Respir. Physiol. 62, 341-348.

Cameron, J. N., 1979a. Excretion of $\mathrm{CO}_{2}$ in water breathing animals; a short review. - Mar. Biol. Lett. $1,3-13$.

Cameron, J. N., 1979b. Effects of inhibitors on ion fluxes, transgill potential and pH regulation in freshwater blue crabs Callinectes sapidus (Rathbun). - J. comp. Physiol. 133, 219-225.

Clarke, B. \& Porteous J. W., 1964. Determination of succinic acid by an enzymic method. - Biochem. J. $93,21 \mathrm{c}-22 \mathrm{c}$.

Ehrenfeld, J., 1974. Aspects of ionic transport mechanisms in crayfish Astacus leptodactylus. - J. exp. Biol. 61, 57-70.

Ferguson, J. K. W., Lewis, L. \& Smith, J., 1937. The distribution of carbonic anhydrase in certain marine invertebrates. - J. cell comp. Physiol. 10, 395-400. 
Gieen, J. D. \& Narahara, H. T., 1980. Assay of succinate dehydrogenase activity by the tetrazolium method: evaluation of an improved technique in skeletal muscle fractions. - J. Histochem. Cytochem. 28, 408-412.

Henry, R. P. \& Cameron, J. N., 1982. The distribution and partial characterization of carbonic anhydrase in selected aquatic and terrestrial decapode crustaceans. - J. exp. Zool. 221, 309-321.

Henry, R. P. \& Kormanik, G. A., 1985. Carbonic anhydrase activity and calcium deposition during the molt cycle of the blue crab, Callinectes sapidus. - J. crust. Biol. 5, 234-241.

Henry, R. P., 1987. Quaternary ammonium sulfanilamid. A membrane-impermeant carbonic anhydrase inhibitor. - Am. J. Physiol. 252 (Reg. Integr. Comp. Physiol. 21), R959-R965.

Henry, R. P., 1988a. Subcellular distribution of carbonic anhydrase activity in the gills of the blue crab, Callinectes sapidus. - J. exp. Zool. 245, 1-8.

Henry, R. P., 1988b. Multiple functions of carbonic anhydrase in the crustacean gill. - J. exp. Zool. 248, 19-24.

Kosiol, B., Bigalke, T. \& Graszynski, K., 1988. Purification and characterization of gill $\mathrm{Na}^{+} / \mathrm{K}^{+}$. ATP'ase in the freshwater crayfish Orconectes limosus Rafinesque. - Comp. Biochem. Physiol. $89 B, 171-177$.

Maren, T. H., 1967. Carbonic anhydrase: chemistry, physiology and inhibition. - Physiol. Rev. 47, $595-781$.

Meldrum, N. U. \& Roughton, F. J. W., 1932. The $\mathrm{CO}_{2}$ catalyst present in blood. - J. Physiol., Lond. 75, 15.

Onken, H. \& Graszynski, K., 1989. Active $\mathrm{Cl}^{-}$absorption by the Chinese crab (Eriocheier sinensis) gill epithelium measured by transepithelial potential difference. - J. comp. Physiol. 1598, 21.

Onken, H., Graszynski, K. \& Zeiske, W., 1991. Na -independent, electrogenic $\mathrm{Cl}^{-}$uptake across the posterior gills of the chinese crab (Eriocheir sinensis): voltage-clamp and microelectrode studies. - J. comp. Physiol. 161B, 293.

Onken, H. \& Siebers, D., 1992. Voltage-clamp measurements on single split lamellae of posterior gills of the shore crab Carcinus maenas. - Mar. Biol. 114, 385-390.

Onken, H., Graszynski, K., Johannsen, A., Putzenlechner, M., Riestenpatt, S., Schirmer, C., Siebers, D. \& Zeiske, W., 1995. How to overcome osmotic stress? Marine crabs conquer freshwater. New insights from modern electrophysiology. - Helgoländer Meeresunters. 49, 715-725.

Pequeux, A. \& Gilles, R., 1988. The transepithelial potential differrence of isolated perfused gills of the Chinese crab Eriocheir sinensis acclimated to fresh water. - Comp. Biochem. Physiol. 89A, 163-172.

Scalera, V., Storelli, C., Storelli-Joss, Ch., Haase, W. \& Murer, H., 1980. A simple and fast method for the isolation of basolateral plasma membranes from rat small-intestinal epithelial cells. Biochem. J. 180,177 .

Sedmark, J. J. \& Grossberg, S. E., 1977. A rapid, sensitive and versatile assay for protein using coomassie brilliant blue G250. - Analyt. Biochem. 79, 544-552.

Sobotka, H. \& Kann, S., 1941. Carbonic anhydrase in fishes and invertebrates. - J, cell comp. Physiol. $17,341-348$.

Towle, D. W. \& Kays, W. T., 1986. Basolateral localization of $\mathrm{Na}^{+} / \mathrm{K}^{+}$ATP'ase in gill epithelium of two osmoregulating crabs, Callinectes sapidus and Carcinus maenas. - J. exp. Zool. 239, 311-318. 